\title{
Use of oxidative stress biomarkers in Carcinus maenas to assess littoral zone contamination in Tunisia
}

\author{
Jihene Ghedira ${ }^{1}$, Jamel Jebali ${ }^{1}$, Mohamed Banni ${ }^{1}$, Lassaad Chouba ${ }^{2}$, \\ Hamadi Boussetta ${ }^{1}$, Juan López-Barea ${ }^{3}$, José Alhama ${ }^{3, *}$ \\ ${ }^{1}$ Laboratory of Biochemical and Environmental Toxicology, Higher Institute of Agriculture, Chott-Mariem, 4042 Sousse, \\ Tunisia \\ ${ }^{2}$ Chemical Laboratory, Higher Institute of Marine Sciences and Technology, La Goulette Center, 2060 Tunis, Tunisia \\ ${ }^{3}$ Department of Biochemistry and Molecular Biology, University of Córdoba, Severo Ochoa Building, Rabanales Campus, \\ Highway A4, Km 396a, 14071 Córdoba, Spain
}

\begin{abstract}
Biological effects of pollutants were studied in Carcinus maenas crabs from 3 polluted sites (Bizerte, Teboulba, Gargour) along the Tunisian littoral zone using biochemical biomarkers. A metal contamination gradient was found, Bizerte standing out as the most metalpolluted area. Gargour animals nonetheless showed higher oxidative stress responses, such as glutathione reductase and 6-phosphogluconate dehydrogenase activities, as well as malondialdehyde (MDA) levels in gills. The gills showed higher lipid peroxidation than did the digestive gland, in keeping with their respiratory role. Animals were also exposed for different periods to 2 model pollutants, cadmium and chlorpyriphos-ethyl. Although cadium induces oxidative stress, mainly in gills, thus increasing lipid peroxidation, principal-component analysis indicated that metal content in sediments and crabs from in-field monitoring does not fully correlate with oxidative stress biomarker responses. Catalase and MDA were the most sensitive biomarkers, and gills the most responsive organ. A lower catalase content in gills was linked to higher MDA levels.
\end{abstract}

KEY WORDS: Biomonitoring · Biochemical effects · Antioxidant enzymes · Lipid peroxidation · Multivariate analysis $\cdot$ Digestive gland $\cdot$ Gills $\cdot$ Metals $\cdot$ Organophosphates $\cdot$ Sediment pollution

\section{INTRODUCTION}

The marine environment is threatened by increasing levels of pollutants from many anthropogenic activities, including urban, agricultural and industrial discharges. This endangers the health of organisms and affects the marine ecosystem and humans consuming food of marine origin. Levels of metals, pesticides and hydrocarbons are increasing along the Tunisian littoral zone, especially at Bizerte Lagoon (Dellali et al. 2001, Khessiba et al. 2001, Louiz et al. 2009, Bouraoui et al. 2010) and in the area of Sfax/ Gabès gulf (Louati et al. 2001, Hamza-Chaffai et al. 2003, Zaghden et al. 2005, Machreki-Ajmi et al. 2008, Bouraoui et al. 2010). Although both areas are sub- ject to many ecological pressures, they are, due to the variety of fishing and aquaculture activities, key aquatic resources.

The diversity of chemicals dumped into the marine environment, the costs of chemical measurement of water and sediment quality, and the difficulty of evaluating the toxicity of pollutant mixtures has led to increasing use of biomarkers in marine organisms (Dellali et al. 2001, Banni et al. 2009a, Bouraoui et al. 2010). Biomarkers are useful for assessing chemical exposure and for predicting the detrimental effects of contaminants before damage reaches higher organizational levels (Monserrat et al. 2003). Many contaminants, including organic compounds and metals, convert $\mathrm{O}_{2}$ into reactive oxygen species (ROS) that 
are highly toxic and mutagenic. ROS damage various biomolecules, such as fatty acids that generate oxidized by-products, including malondialdehyde (MDA) (Gutteridge 1984, Brown \& Kelly 1996).

Aerobic organisms have several lines of defence against oxidative stress (Sies 1986). Primary antioxidant enzymes such as catalase (CAT) detoxify ROS. Glutathione peroxidase (GPX) reduces reactive lipid hydroperoxydes to prevent MDA formation (Flohé 1989). Glutathione-S-transferases (GSTs) conjugate electrophilic compounds to reduced glutathione (GSH), and some GSTs play significant roles in the detoxification of lipid peroxidation by-products (Pickett 1989). Ancillary enzymes such as 6-phosphogluconate dehydrogenase (6PGDH) recycle $\mathrm{NADP}^{+}$into its reduced form (NADPH). Then glutathione reductase (GR) uses NADPH to turn oxidized glutathione (GSSG) into GSH, which keeps cytosol reduced (Sies 1986). Biochemical biomarkers, including antioxidant enzymes and evidence of oxidative damage to biomolecules, are powerful tools for detecting the exposure and biological effects of pollutants, allowing early detection of environmental problems (LópezBarea 1995, Monserrat et al. 2003, Martín-Díaz et al. 2004, Vioque-Fernández et al. 2009, Bouraoui et al. 2010). Chemical analysis and biomarker assessment, when combined, can offer more complete and biologically relevant information on the impact of pollutants on organism health (Martín-Díaz et al. 2005, Allan et al. 2006).

The shore crab Carcinus maenas was selected as a 'model organism'. C. maenas, a eurythermal and euryhaline species (Hebel et al. 1997), is a common littoral crab and an important invasive species, widespread along the Mediterranean coast (Carlton \& Cohen 2003). Its long life cycle, wide distribution, and sedentary lifestyle make it a good bioindicator for assessment of contaminant effects in situ (MartínDíaz et al. 2009, Montes Nieto et al. 2010) or under controlled conditions (Martín-Díaz et al. 2005, 2007, 2008). It can be exposed to relatively high levels of a broad range of contaminants, yet remain common and abundant, without apparent detrimental effects (Pedersen et al. 1998). This suggests that compensatory mechanisms which allow the shore crab to survive natural environmental fluctuations may also confer some degree of tolerance to contaminant exposure (Hebel et al. 1997, Brown et al. 2004).

Exposure to toxic metals has become an increasing source of disease. Due to its widespread industrial use, Cd, a non-essential metal, is a ubiquitous and increasingly common contaminant of great ecological and human concern. Due to its wide range of organ toxicity and to its 10 to $30 \mathrm{yr}$ half-life, $\mathrm{Cd}$ is one of the most hazardous substances known (Patrick 2003). In crustaceans, $\mathrm{Cd}$ is accumulated in key organs, including digestive glands and gills (Ray 1986), where it becomes toxic through any of various mechanisms (Simpson 1981, Rainbow 1998): (1) alteration of sulfhydryl homeostasis by GSH depletion and binding to protein thio (-SH) groups, which decreases its antioxidant capacity by inhibiting antioxidant enzymes (Casalino et al. 2002, Patrick 2003, Valko et al. 2005, Pan \& Zhang 2006, Silvestre et al. 2006); (2) displacement of $\mathrm{Zn}$ and Se in metallo-enzymes, decreasing their activity (Patrick 2003); (3) displacement of $\mathrm{Fe}^{2+}$, which induces ROS via a Fenton reaction (Casalino et al. 1997); or (4) generation of lipid peroxidation and DNA damage (Casalino et al. 1997, 2002, Patrick 2003, Pan \& Zhang, 2006). Organophosphates (OPs) are highly neurotoxic synthetic insecticides used to control agricultural pests (Banni et al. 2005, Vioque-Fernández et al. 2007, Ghedira et al. 2009). They are widely used in the north of Tunisia to treat cereal pathologies. They often end up in aquatic habitats, carried there by wind, runoff, or uncontrolled waste disposal, thus threatening freshwater and marine ecosystems, especially during the rainy season (Dellali et al. 2001, Jebali et al. 2007, Ghedira et al. 2009).

In the present study, biochemical biomarkers were used to assess the exposure and biological effects of pollutants in Carcinus maenas collected from relatively polluted sites along the Tunisian littoral zone. Parallel to this, crabs were exposed to $\mathrm{Cd}$ and chlorpyriphos-ethyl (cPFe), to evaluate their biochemical responses to 2 representative models of metals and pesticides.

\section{MATERIALS AND METHODS}

\section{Sampling sites, animals and handling}

In October 2006, intermoult Carcinus maenas (n = 8; length: 45 to $55 \mathrm{~mm}$ ) were manually collected at 3 different sites from the north and eastern coast of Tunisia (Fig. 1). Many industries (e.g. cement, textile, electronic, metallurgical, tyre manufacturing, oil refineries) are located in Bizerte, an area of high growth and intense urbanization, with a busy shipyard and commercial harbour (Dellali et al. 2001, Khessiba et al. 2001, Louiz et al. 2009, Bouraoui et al. 2010). Agricultural waste reaches Bizerte Lagoon (area: $150 \mathrm{~km}^{2}$ ) through runoff from nearby cereal fields, where fertilizers are used at the rate of $20.5 \mathrm{t}$ 


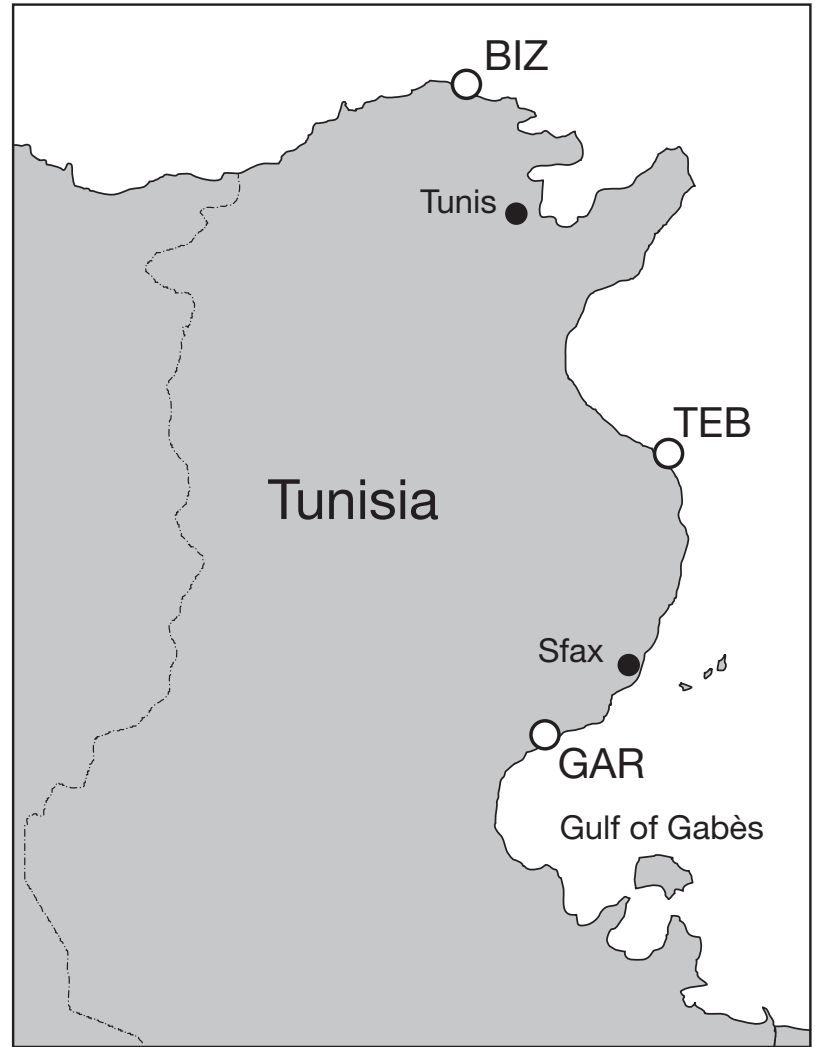

Fig. 1. Sampling sites within the Tunisian littoral zone. BIZ: Bizerte Lagoon; TEB: Teboulba; GAR: Gargour

$\mathrm{yr}^{-1}$ (ANPE 1989). The Gabès Gulf is a major aquatic resource, contributing $65 \%$ of national aquaculture production (CGP 1996). Sfax is the second largest city in Tunisia, the fourth busiest commercial harbour, and the major industrial area in the south. Crude phosphate treatments, chemical industries, tanneries, and plastics plants release pollutionloaded effluents into the marine environment; these pollutants include toxic metals, which are washed back by tides to the littoral area (Louati et al. 2001, Banni et al. 2005, Zaghden et al. 2005, MachrekiAjmi et al. 2008, Smaoui-Damak et al. 2009). Cd from phosphate plants is one of the main contaminants in the Gabès area (Hamza-Chaffai et al. 2003, SmaouiDamak et al. 2003, Machreki-Ajmi et al. 2008). Samples were collected from: (1) Bizerte (BIZ) Lagoon, and (2) Gargour (GAR), in Gabès Gulf, both of which areas receive urban, industrial and agricultural pollution, and (3) Teboulba (TEB), with no main contamination sources and considered a reference site in many field studies (Banni et al. 2007, Jebali et al. 2007, Bouraoui et al. 2010).

Crabs from these areas were transported alive to the laboratory immediately upon collection in buck- ets with aerated seawater. Once there, the cephalothorax was opened on ice and the digestive gland and gills were quickly removed. For metals analysis, organs were freeze-dried and ground; for biochemical studies, they were frozen at $-80^{\circ} \mathrm{C}$, ground in a mortar with liquid $\mathrm{N}_{2}$, and stored at $-80^{\circ} \mathrm{C}$ until use.

Three samples of surface sediments (up to $10 \mathrm{~cm}$ depth), collected in the same place where the crabs were sampled, were mixed, transported to the laboratory and freeze-dried for $12 \mathrm{~h}$. After removal of large plant fragments, they were sieved to obtain the fine fraction $(<60 \mu \mathrm{m})$, which was stored at $4^{\circ} \mathrm{C}$ until metals analysis.

\section{Metals analysis}

Metals were analysed in the sediment samples and crab organs by atomic absorption spectrophotometry (AAS). Both sediment samples and freeze-dried organs $(0.2 \mathrm{~g})$ were digested for $35 \mathrm{~min}$ in a mixture of $5 \mathrm{ml}$ concentrated $\mathrm{HNO}_{3}$ and $2 \mathrm{ml} \mathrm{HF}$ in a microwave oven (Ethos) set at $100 \%$ power and 120 psi. After digestion, samples were diluted with Milli-Q water, and $9.8 \mathrm{~g}$ of $\mathrm{H}_{3} \mathrm{BO}_{3}$ was added (PNUE/ COI/AIEA/FAO 1994). Concentrations of $\mathrm{Cd}, \mathrm{Pb}$, and $\mathrm{Cu}$ were determined by AAS with graphite furnace using a Vectra $220 \mathrm{Z}$ spectrophotometer (Varian) with ZEEMAN correction. Zn concentration was determined by an AA 10 flame AAS (Varian). Total Hg was determined by cold vapour technique, employing a VGA system coupled to a spectrophotometer using a reducing dissolution of $\mathrm{SnCl}_{2}$ in $\mathrm{HCl}$. Quality assurance was assessed using dogfish liver International Atomic Energy Agency (IAEA) 405 as reference material. Standards were treated and analysed under the same conditions as the sediment and organ samples. All metal concentrations are reported in

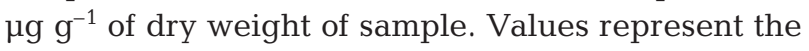
mean of 2 independent extractions from the sediment and organ samples.

\section{Exposure of crabs to $\mathrm{Cd}$ and $\mathrm{cPFe}$}

Crabs from TEB were transported alive to the laboratory as described above. There were divided into 4 groups of 8 , placed in plastic tanks with $10 \mathrm{l}$ of seawater $\left(37 \pm 1 \%\right.$ salinity) and maintained at $17.2^{\circ} \mathrm{C}$. Animals were fed regularly with diced fish every $3 \mathrm{~d}$. After $7 \mathrm{~d}$ of acclimation, Group 1 was exposed to $500 \mu \mathrm{g} \mathrm{l}^{-1} \mathrm{CdCl}_{2}$ (Merck), Group 2 to $3.12 \mu \mathrm{g} \mathrm{l}^{-1} \mathrm{CPFe}$ (Dursban ${ }^{\circledR}$ ), and Group 3 to a mixture of $\mathrm{Cd}$ and $\mathrm{OP}$ 
at the concentrations indicated above (all nominal values). Group 4, the control group, received no treatment. After $2 \mathrm{~d}$ exposure, all crabs were sacrificed. For each of the 4 groups, the digestive gland and gills were carefully removed and frozen at $-80^{\circ} \mathrm{C}$ until analysis. The concentrations of $\mathrm{Cd}$ and $\mathrm{CPFe}$, chosen as suggested in the literature (Schuwerack et al. 2001, Schuwerack \& Lewis 2003), were well below their respective $\mathrm{LC}_{50}$. (The $\mathrm{LC}_{50}$ of $\mathrm{CPFe}$ for the adult crab Eriocheir sinensis, e.g. is $460.9 \mathrm{\mu g} \mathrm{l}^{-1}$; Li et al. 2006).

\section{Cell-free extract preparations and biomarker assays}

All steps for cell-free extract preparation were carried out at $4{ }^{\circ} \mathrm{C}$. Organs were ground up and disrupted in a T 25 Ultra-Turrax ${ }^{\circledR}$ (Janke \& Kunkel) in $10 \mathrm{mM}$ Tris $\mathrm{HCl}(\mathrm{pH}$ 7.5) containing $1 \mathrm{mM}$ EDTA, $1 \mathrm{mM}$ GSH and $1 \mathrm{mM}$ phenylmethylsulfonyl fluoride at a concentration of $3 \mathrm{ml} \mathrm{g}^{-1}$. For the MDA assay, $300 \mu \mathrm{l}$ of homogenate was set apart and the rest centrifuged for 20 min on a Beckman J2-21 centrifuge at $10000 \times g$. Supernatants were stored at $-20^{\circ} \mathrm{C}$ for no longer than 1 wk until biomarker determinations.

The cytosolic activities of primary and ancillary antioxidant enzymes, and phase II biotransforming enzymes were assayed (as published) as biomarkers (Rodríguez-Ariza et al. 1992). CAT was measured at $240 \mathrm{~nm}$ with $20 \mathrm{mM} \mathrm{H}_{2} \mathrm{O}_{2}$. GPX followed at $340 \mathrm{~nm}$ with $1 \mathrm{mM}$ GSH, $2 \mathrm{mM}$ cumene hydroperoxide, $0.24 \mathrm{U}$ GR and $0.15 \mathrm{mM}$ NADPH. 6PGDH was analyzed at $340 \mathrm{~nm}$ with $1 \mathrm{mM}$ 6-phosphogluconate and $0.25 \mathrm{mM} \mathrm{NADP}^{+}$. GR was assayed at $340 \mathrm{~nm}$ with $2.5 \mathrm{mM}$ GSSG and $0.12 \mathrm{mM}$ NADPH. GST was determined at $340 \mathrm{~nm}$ with $2 \mathrm{mM}$ GSH and 2 mM 1-chloro-2,4-dinitrobenzene. Data were expressed as $\mathrm{mU} \mathrm{mg}^{-1}$ protein, one unit being defined as $\mu \mathrm{mol}$ of substrate consumed, or of product formed, per min. Thiobarbituric-acid-reactive substances were fluorometrically assayed using $515 \mathrm{~nm}$ excitation and 550 nm emission to assess the MDA level, a known biomarker of lipid oxidative damage (Brown \& Kelly 1996). MDA was expressed as nmol MDA $\mathrm{mg}^{-1}$ protein. Total protein content was measured at $595 \mathrm{~nm}$ following the Bradford method (Bradford 1976), using bovine serum albumin as the standard.

\section{Statistical analysis}

The numbers represent the mean \pm SD of 3 independent extractions with 3 assays per extract. Statistical significance of the results compared to the reference was determined by Student's $t$-test using InStat ${ }^{\mathrm{TM}}$ software, v. 2.01/93 (GraphPad), after checking normality of data and homogeneity of variance. Factorial analysis was also performed to determine the major responses with respect to metal levels. Factor analysis using principal component analysis (PCA) was applied to the original sets of variables using the SPSS Statistics 17 package. Using this same software, a correlation between metal concentrations and biomarker responses was undertaken using a Pearson correlation analysis. Results were considered significant at $\mathrm{p}<0.05$.

\section{RESULTS AND DISCUSSION}

\section{Metal concentrations in sediments and crab organs}

To evaluate metal pollution levels in the Tunisian littoral zone, concentrations of 5 elements were determined in sediments (Table 1). BIZ stood out as the most metal-polluted area. The levels of all metals in the sediments were much higher at BIZ than at GAR and at the reference site TEB. Pb levels were $>11$ times higher, $\mathrm{Cd}$ and $\mathrm{Cu}>9$ times higher, $\mathrm{Zn}>6.8$ times higher and $\mathrm{Hg}>2.5$ times higher at BIZ than at TEB. Cu levels at BIZ were 56 times higher than at GAR, which in turn had higher levels of $\mathrm{Cd}, \mathrm{Pb}$ and $\mathrm{Hg}$ than TEB. Cu levels, however, were 6 times

Table 1. Metal content ( $\mu \mathrm{g} \mathrm{g}^{-1}$ dry wt) in sediments, and digestive gland and gills of Carcinus maenas from 3 sampling sites along the Tunisian coast. TEB: Teboulba; BIZ: Bizerte Lagoon; GAR: Gargour. Values represent mean of 2 independent extractions. Numbers in parentheses represent ratio of metal content at BIZ and GAR to TEB. nd = not detected

\begin{tabular}{|c|c|c|c|c|c|c|c|c|c|}
\hline \multirow[t]{2}{*}{ Metal } & \multicolumn{3}{|c|}{ _ Sediment _ـ } & \multicolumn{3}{|c|}{ Digestive gland } & \multicolumn{3}{|c|}{ - Gills } \\
\hline & TEB & $\mathrm{BIZ}$ & GAR & TEB & $\mathrm{BIZ}$ & GAR & TEB & BIZ & GAR \\
\hline $\mathrm{Cd}$ & 0.08 & $\begin{array}{c}0.77 \\
(9.63)\end{array}$ & $\begin{array}{c}0.15 \\
(1.88)\end{array}$ & 0.62 & $\begin{array}{c}21.5 \\
(34.7)\end{array}$ & $\begin{array}{c}3.04 \\
(4.90)\end{array}$ & 0.38 & $\begin{array}{c}0.61 \\
(1.61)\end{array}$ & $\begin{array}{c}0.52 \\
(1.37)\end{array}$ \\
\hline $\mathrm{Pb}$ & 9.34 & $\begin{array}{l}106.5 \\
(11.4)\end{array}$ & $\begin{array}{c}25.9 \\
(2.77)\end{array}$ & 0.67 & $\begin{array}{c}4.50 \\
(6.72)\end{array}$ & $\begin{array}{c}0.14 \\
(0.21)\end{array}$ & 15.57 & $\begin{array}{c}21.1 \\
(1.36)\end{array}$ & $\begin{array}{c}4.94 \\
(0.32)\end{array}$ \\
\hline $\mathrm{Cu}$ & 12.49 & $\begin{array}{l}116.6 \\
(9.34)\end{array}$ & $\begin{array}{c}2.08 \\
(0.17)\end{array}$ & 396.9 & $\begin{array}{l}863.5 \\
(2.43)\end{array}$ & $\begin{array}{l}205.1 \\
(0.52)\end{array}$ & 376.5 & $\begin{array}{l}857.3 \\
(2.28)\end{array}$ & $\begin{array}{l}238.9 \\
(0.63)\end{array}$ \\
\hline $\mathrm{Zn}$ & 176.9 & $\begin{array}{c}1208.9 \\
(6.83)\end{array}$ & $\begin{array}{l}173.5 \\
(0.98)\end{array}$ & 102.4 & $\begin{array}{l}985.1 \\
(9.62)\end{array}$ & $\begin{array}{c}99.9 \\
(0.98)\end{array}$ & 83.4 & $\begin{array}{l}627.1 \\
(7.52)\end{array}$ & $\begin{array}{c}88.8 \\
(1.06)\end{array}$ \\
\hline $\mathrm{Hg}$ & 0.19 & $\begin{array}{c}0.49 \\
(2.58)\end{array}$ & $\begin{array}{c}0.24 \\
(1.26)\end{array}$ & nd & nd & nd & nd & nd & nd \\
\hline
\end{tabular}


higher at TEB than at GAR. Notably, except for Cd, values at BIZ were above effects range-low (ERL) levels of the sediment quality guidelines proposed by Long et al. (1995; Cd: 1.2, Pb: 47, Cu: 34, Zn: $150 \mu \mathrm{g}$ $\mathrm{g}^{-1}$ ). At GAR and TEB, only Zn showed values higher than ERL levels. Recently, evidence of reproduction alterations and gonadal lesions related to pollution stress has appeared in BIZ fish, causing an upsetting drop in fish productivity during the last few years (Louiz et al. 2009).

Carcinus maenas is widely distributed, has many sediment-burrowing features and exhibits a wandering lifestyle, roaming over muddy substrates in coastal areas. When these animals are exposed to metal pollution within their habitats, toxic metal loads accumulate and subsequently have a biological effect on the crabs. Bioaccumulation of the 5 selected metals was evaluated in the digestive gland and gills of $C$. maenas from the 3 study sites (Table 1). In agreement with the results obtained in the sediments, the levels of metals were higher in organs from BIZ animals, except for $\mathrm{Hg}$, which was not detected in the studied organs. In the divestive gland, Cd at BIZ was 34.7 times the levels found in C. maenas at TEB; $\mathrm{Pb}$ and Zn levels in BIZ animals were, respectively, 6.72 and 9.62 times higher than in TEB animals. Cd was 4.9 times higher in GAR crabs than in TEB crabs, while $\mathrm{Pb}$ and $\mathrm{Cu}$ levels were higher in TEB animals. In gills, importantly, Zn levels were 7.52 times higher in BIZ animals than in TEB animals. Crude phosphate treatment industries located at Sfax are suggested as the main source of the $\mathrm{Cd}$ found in the sediments (1.9 times higher than TEB levels) and in the digestive gland of the GAR crabs (4.9 times higher than in TEB animals). On the other hand, it is relevant to highlight the significantly high levels of all analyzed metals in BIZ sediments as compared to TEB sediments $(\mathrm{Cd}, \mathrm{Pb}$, and $\mathrm{Zn} \sim 10$ times higher in BIZ sediments than TEB). This is probably due to the intensive industrial and agricultural activities carried out in this area. Our results agree with those previously described for the nereid worm Nereis (Heiste) diversicolor, which showed the highest content of heavy metals at BIZ (Cd levels 19.4 times, Cu levels 4.6 times, and $\mathrm{Zn}$ levels 3.4 times those measured in animals at TEB), lower levels at GAR (Cd levels 4.7 times those measured in animals at TEB) and the lowest levels at TEB (Bouraoui et al. 2010).

Differences in the distribution of metals in the organs were also apparent. Thus, although a fairly similar accumulation of the 2 essential metals, $\mathrm{Cu}$ and $\mathrm{Zn}$, was found in both organs, Cd was higher in the digestive gland than in the gills, while the gills showed much higher $\mathrm{Pb}$ levels. $\mathrm{Cu}$ bioaccumulation was detected in both organs, $\mathrm{Cu}$ being $\sim 30$ times higher in Carcinus maenas at TEB, $\sim 7.5$ times higher in animals at BIZ, and 100 times higher in animals at GAR than in the corresponding sediments. Significantly, $\mathrm{Cd}$ bioaccumulation was also found in the digestive gland, with levels in TEB animals 7.8 times higher, levels in BIZ animals 27.9 times higher and levels in GAR animals 20.3 times higher than in the corresponding sediments. Unlike C. maenas, the river crab Potamonautes warreni showed higher $\mathrm{Cd}$ and $\mathrm{Cu}$ contents in gills than in the digestive gland, although $\mathrm{Zn}$ levels were similar in organs from both species (Schuwerack et al. 2001). When crabs are exposed to Cd without other metals, the highest content is found in gills. When they are exposed to $\mathrm{Cd}$ in company with other metals, Cd values are highest in the digestive gland (Martín-Díaz et al. 2005). Cd accumulation was also found to be higher in the digestive gland of the cockle Cerastoderma glaucum from Gabès Gulf than in the gills (Machreki-Ajmi et al. 2008).

\section{In-field biomarker responses}

Chemical monitoring to assess environmental quality has its limitations, and therefore biological monitoring, including the use of biomarkers, is strongly recommended in monitoring programmes (Allan et al. 2006). Application of biochemical biomarkers under field conditions has been proposed by many investigators to assess chronic responses and to address the integrated effects of anthropogenic and environmental stressors. ROS formation has been proposed as the basis of the toxicity of many contaminants, including metals and organic compounds. For this reason, biochemical biomarkers responsive to oxidative stress were used to determine pollution levels along the Tunisian littoral zone (Fig. 2). Compared to TEB, CAT activity was lower in the digestive gland of BIZ animals (1.5 times less, p < 0.01), and even lower in animals from GAR $(3.7$ times less, $p<$ 0.001). The gills from these 2 metal-polluted sites showed more drastic CAT decreases (from 3.9- to 4.8fold, $\mathrm{p}<0.001$ ) than what was observed in control animals from TEB. Antioxidant enzymes, including CAT, decrease with time or with exposure to high metal levels (Pan \& Zhang 2006). CAT activity has also shown as a sensitive biomarker in other studies, since Procambarus clarkii crayfish from polluted areas showed lower activity than the reference animals (Vioque-Fernández et al. 2009). Decreased CAT 

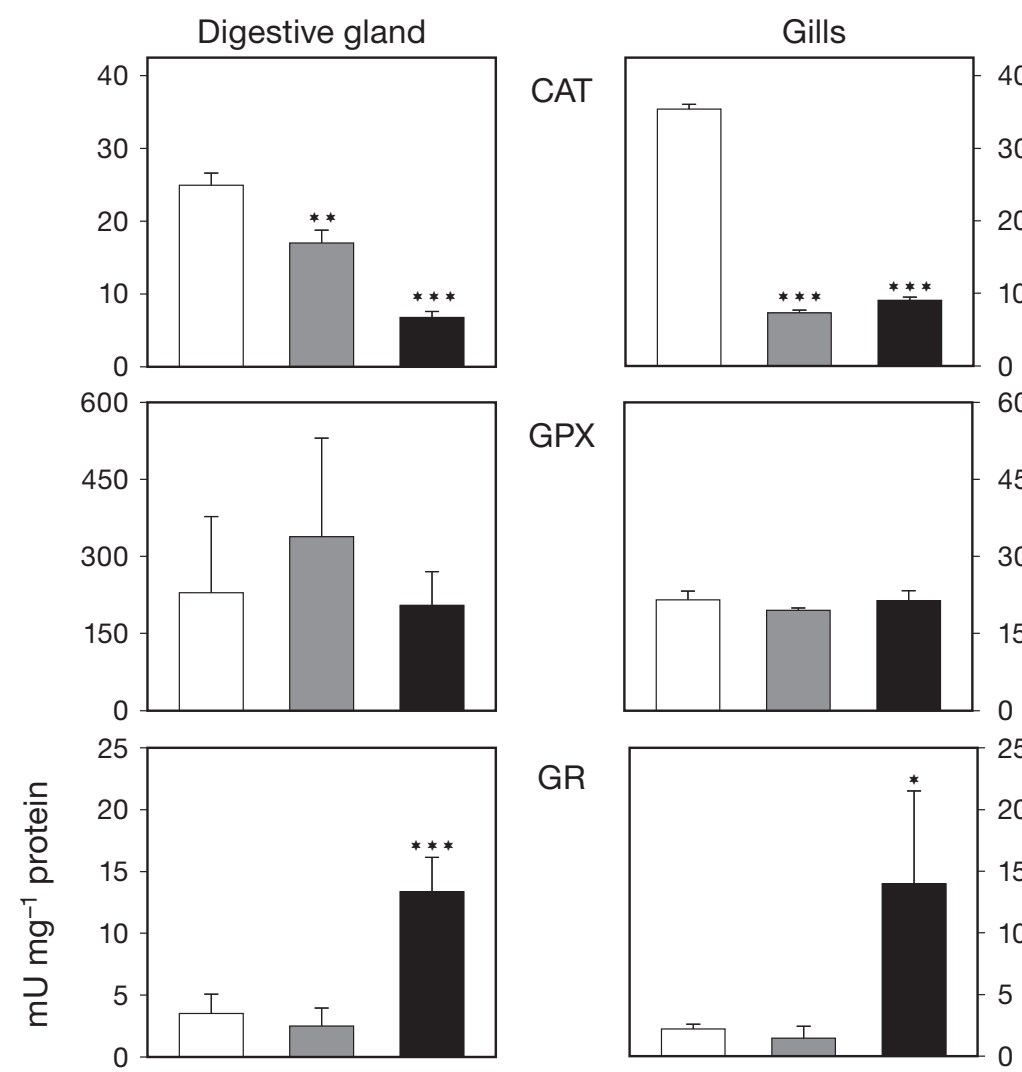

GPX

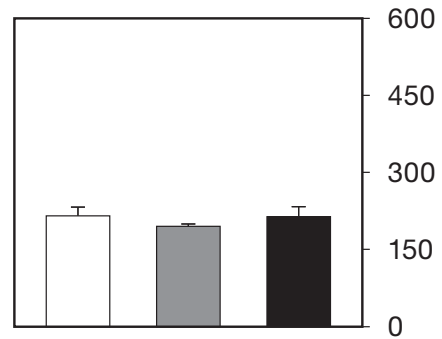

GR
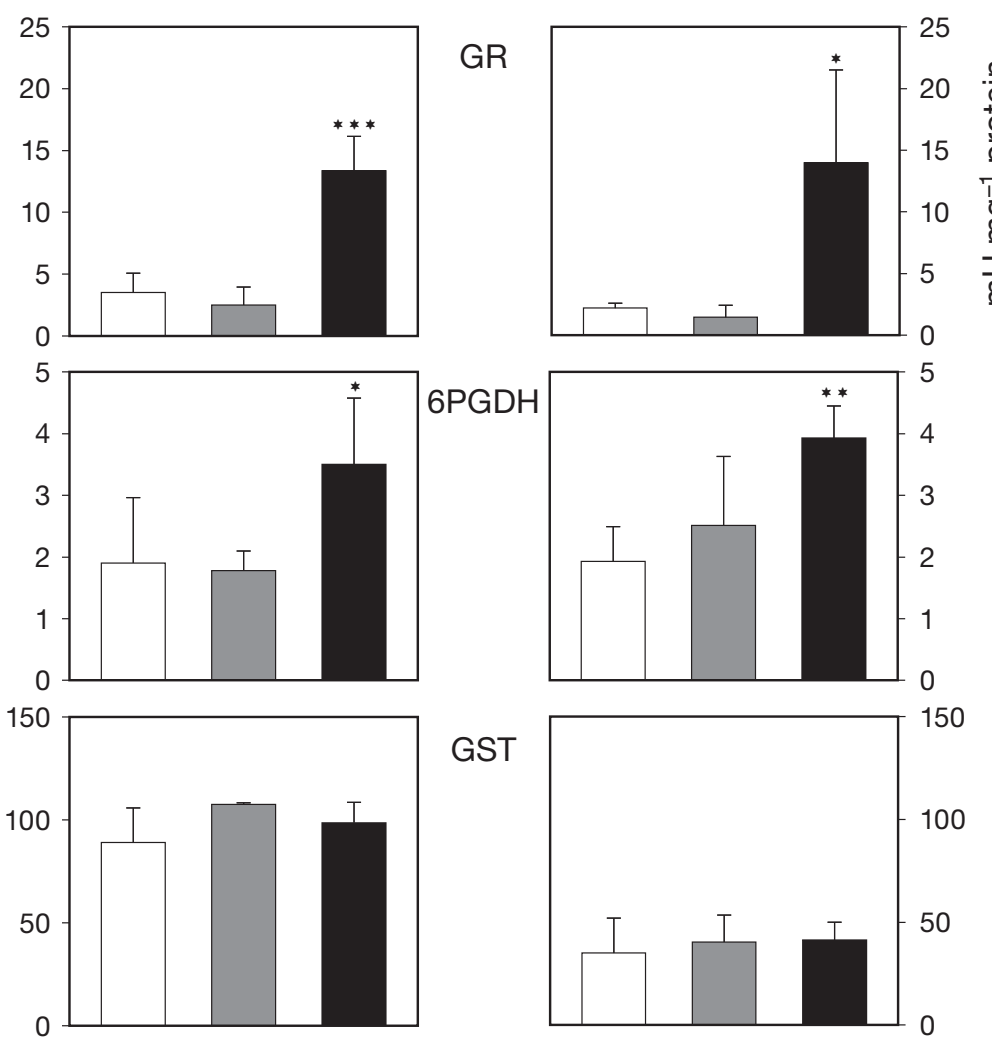

GST
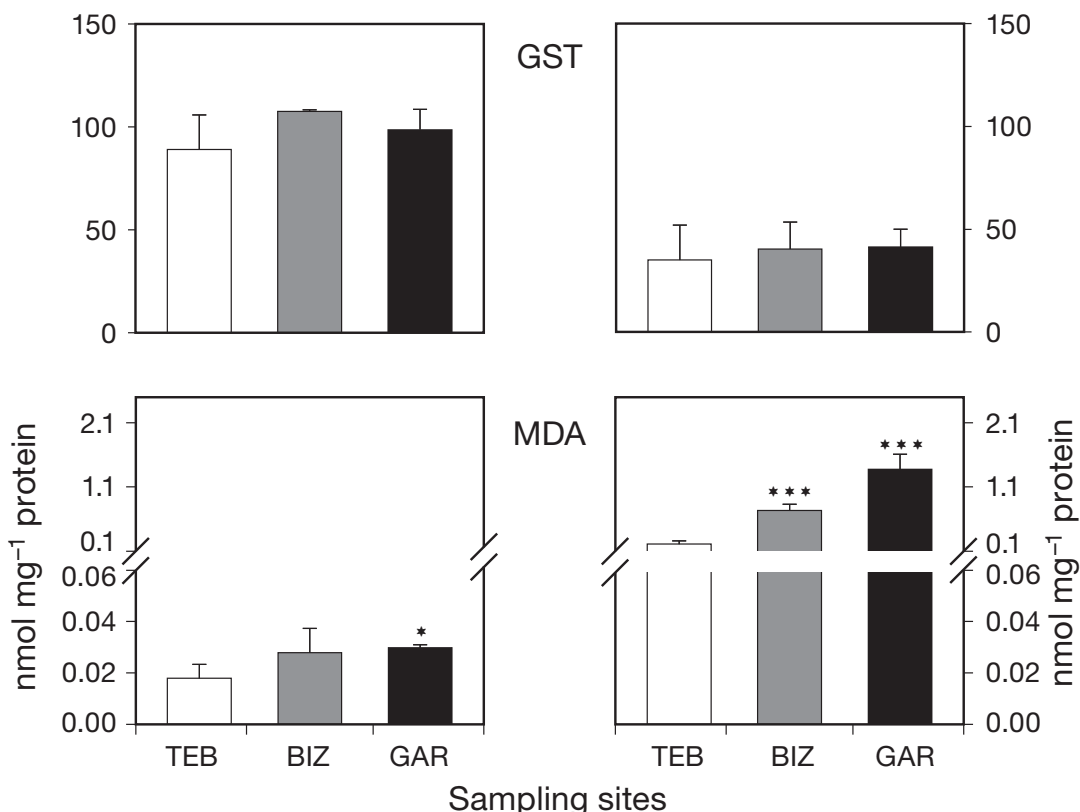

activity has also been reported in mice dwelling at sites contaminated by toxic metals (Montes-Nieto et al. 2007). It is noteworthy, however, that other investigators have found higher CAT activity in clams and worms from BIZ and from sites near Sfax than at control sites (Jebali et al. 2007, Banni et al. 2009b, Bouraoui et al. 2010).

Although BIZ was the most metalpolluted area, GAR crabs had more extensive symptoms of oxidative stress compared to control animals from TEB, as indicated by the increased activity of the 2 antioxidant auxiliary enzymes, GR and 6PGDH, and mostly by a higher MDA content, showing increased damage to lipids. Thus, GR and 6PGDH were higher in both organs of GAR crabs but not in those from BIZ animals, with the highest increases in GAR animals being found in GR rather than in 6PGDH (GR 3.8 times higher in the digestive gland, $\mathrm{p}<0.001 ; 6.4$ times higher in gills, $\mathrm{p}<0.05 ; 6 \mathrm{PGDH} \sim 1.9$ times higher in both organs). Similarly, MDA was higher in the digestive gland of GAR crabs $(p<0.05)$, but even higher in gills $(p<0.001)$ from the 2 most polluted areas, with the highest levels in GAR crabs (6.6 times levels measured in control animals) than in BIZ (3.5 times levels measured in control animals). Greater DNA damage (8-oxodG) has also been found in clams at BIZ and Gabès Gulf sites (Jebali et al. 2007). Oxida-

Fig. 2. Carcinus maenas. Concentrations of biomarkers analyzed in the digestive gland and gills of crabs from 3 sites (see Fig. 1). One unit (U) is defined as $\mu \mathrm{mol}$ of substrate consumed, or of product formed, per min. CAT: catalase; GPX: glutathione peroxidase; GR: glutathione reductase; 6PGDH: 6phosphogluconate dehydrogenase; GST: glutathione-S-transferase; MDA: malondialdehyde. Data represent mean values $\pm \mathrm{SD}$ of 3 independent extractions with 3 assays per extract. Statistical significance of results based on reference site TEB: ${ }^{* * *} \mathrm{p}<0.001$, ${ }^{* *} \mathrm{p}<0.01,{ }^{*} \mathrm{p}<0.05$ 
tive damage to biomolecules, including lipid peroxidation, DNA damage and enzyme inactivation, occurs when antioxidant systems are overcome by an excessive ROS production (Winston \& Di Giulio 1991). Finally, GPX and GST did not change significantly in any of the studied organs.

\section{Relationships between metals and in-field biomarkers}

A multivariate analysis was performed to compare biomarker responses and metal levels in sediments and in crab organs. According to PCA, 2 principal components described the 25 original variables, explaining $100 \%$ of the total variance (Fig. 3). Each component is described according to the dominant group of variables.

The first principal component, accounting for $65.1 \%$ of the variance, was associated with metal content, in sediments $(s)$, in crab digestive glands $(d g)$ and in gills $(g)$, as well as with an increase in GPX and GST in the digestive gland and a decrease in GPX in the gills. Clearly, the concentrations of all metals analysed were highly correlated with each other (results not shown), both in sediments and in crab organs. The significant positive correlation between GPX $(d g)$, and $\mathrm{Pb}(d g)$ and $\mathrm{Cu}(g)(\mathrm{p}<0.05)$, and the significant negative correlation between
GPX $(g)$, and Cd (s, dg) and Zn $(s, d g, g)(\mathrm{p}<0.05)$ should also be highlighted.

The second component, accounting for $34.9 \%$ of the variance, was associated with CAT, GR, 6PGDH, GST and MDA in both organs (except for GST in the digestive gland), although these 5 biomarkers were not associated with metals. It should be emphasized that CAT activity was negatively correlated with all other biomarkers, especially in the case of CAT $(d g)$ and MDA $(g)(\mathrm{p}<0.01)$. Reduced CAT enzymatic activity, along with increased levels of damaged biomolecules (MDA, oxidized glutathione), evidenced by the oxidative lesions promoted by toxic metals, have also been described in crabs and mice from sites contaminated by toxic metals (Huelva Estuary, SW Spain; Montes-Nieto et al. 2007, Montes Nieto et al. 2010). In contrast, a positive correlation was found between GR $(d g)$, GR $(g)$ and 6PGDH $(d g)(\mathrm{p}<0.05)$, and between GST $(g)$ and MDA $(d g)(\mathrm{p}<0.01)$.

\section{Biochemical responses to $\mathrm{Cd}$ and $\mathrm{cPFe}$}

Cd, discharged from crude phosphate plants near Sfax, is one of the most significant contaminants at Gabès Gulf. Metal analysis showed enormous Cd bioaccumulation in the digestive gland of crabs from BIZ, and a lesser but still significant load in that of GAR animals. Both areas also have important agri-

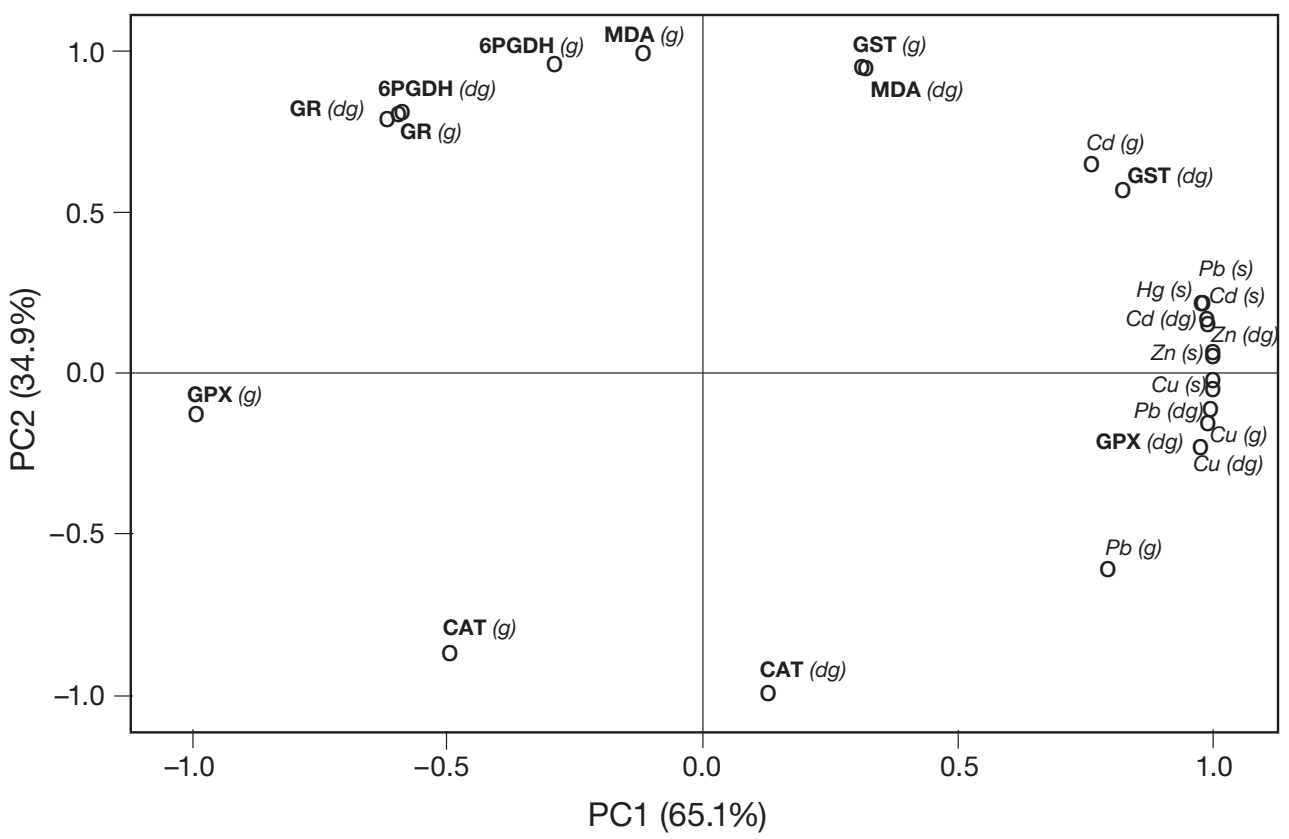

Fig. 3. PCA score plot of PC1 and PC2 of the 25-parameter dataset accounting for $100 \%$ of total variance. Biomarkers (in bold) (see Fig. 2) were analysed in the digestive gland $(d g)$ and gills $(g)$. Metal content (italics) was determined in sediments $(s), d g$ and $g$ 
cultural activity, with increasing levels of pesticides such as OPs (Jebali et al. 2007, Ghedira et al. 2009). Thus, $\mathrm{Cd}$ and $\mathrm{CPFe}$ were chosen as model pollutants in exposure experiments to evaluate their biochemical responses. Fig. 4 shows the effect of $2 \mathrm{~d}$ exposure to $\mathrm{Cd}$ or $\mathrm{CPFe}$ on 8 biomarkers, both in digestive gland and gills. Since crabs inhabiting polluted water bodies are exposed to complex pollutant mixtures, including heavy metals and organic pollutants, exposure to a Cd-cPFE mixture was also monitored to evaluate their combined effect (Fig. 4). CAT activity decreased extensively $(\mathrm{p}<0.001)$ after exposure to $\mathrm{Cd}$, CPFe and the mixture, both in the digestive gland and, to a lesser extent, in gills. Lower GPX activity was also found in the digestive gland, this being significant $(p<0.05)$ only in the mixture, where the effect was synergistic, but not in the gills. An important GR increase was found after exposure to $\mathrm{Cd}$, both in the digestive gland (10.8-fold increase, $\mathrm{p}<0.001)$ and gills (6.5-fold increase, $\mathrm{p}<0.01$ ). GR activity increase was not observed with $\mathrm{CPFe}$ in any organ, but a huge rise ( 20 -fold increase, $\mathrm{p}<0.001$ ) was observed in gills upon exposure to the $\mathrm{Cd}-\mathrm{cPFe}$ mixture. On the other hand, a higher 6PGDH activity was found after exposure to $\mathrm{CPFe}$ and to the mixture in both organs, but only in the digestive gland after $\mathrm{Cd}$ exposure $(\mathrm{p}<$ 0.05 ). While no combined effect of the mixture was observed on 6PGDH activity, a complex effect was ob-

Fig. 4. Carcinus maenas. Biomarkers (see Fig. 2) analysed in the digestive gland and gills of animals exposed for $2 \mathrm{~d}$ to $\mathrm{Cd}$, chlorpyrifos-ethyl (cPFe) and to a mixture of $\mathrm{Cd}$ and $\mathrm{cPFe}$. One unit $(\mathrm{U})$ is defined as $\mu \mathrm{mol}$ of substrate consumed, or of product formed, per min. Data represent mean values \pm SD of 3 independent extractions with 3 assays per extract. Statistical significance of results based on corresponding groups of crabs receiving no treatment, used as control: ${ }^{* * *} \mathrm{p}<0.001,{ }^{* *} \mathrm{p}<0.01,{ }^{*} \mathrm{p}<0.05$

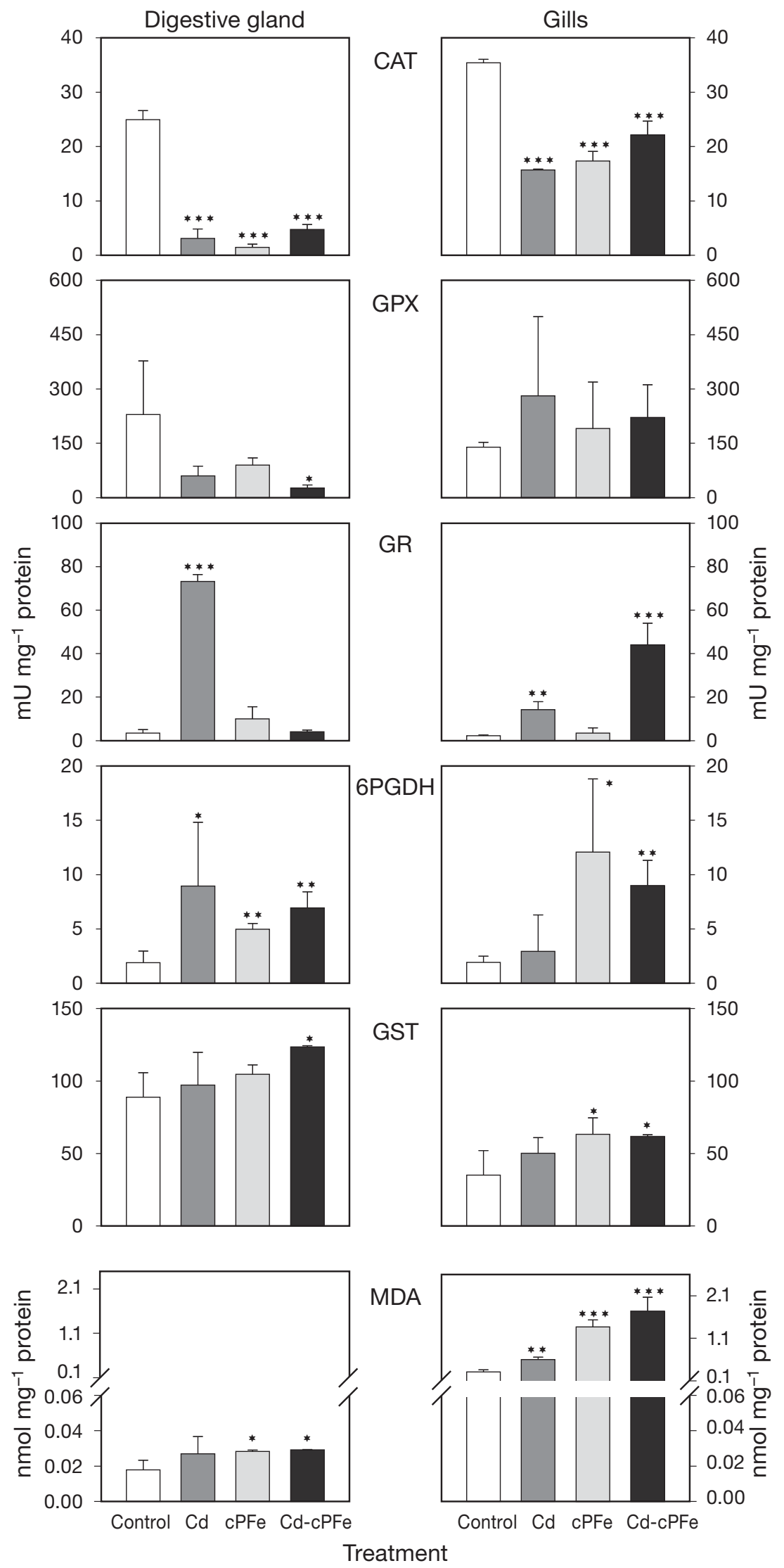


tained with GR, with cPFe exerting an antagonistic effect on the action of $\mathrm{Cd}$ in the digestive gland, and a synergistic effect in gills. A slight but significant $(p<0.05)$, increase in GST activity was found after exposure to $\mathrm{CPFe}$ (gills) or the mixture (both organs), but not to $\mathrm{Cd}$. Although GST is highly induced in insects, being involved in insect resistance to OP pesticides, the response of this enzyme in freshwater invertebrates is low and variable (Hyne \& Maher 2003, Domingues et al. 2009). Parallel to the drastic changes in so many activities related to oxidative stress, MDA increases were detected in gills after exposure to $\mathrm{Cd}(2.4$-fold increase, $\mathrm{p}<0.01)$, but especially to $\mathrm{cPFe}(6.1$-fold increase, $\mathrm{p}<0.001)$ and the mixture ( 7 - to 9-fold increase, $p<0.001$ ), in which an additive effect was observed. In the digestive gland, MDA increased slightly $(\mathrm{p}<0.05)$ after exposure to cPFe and the mixture, but not to $\mathrm{Cd}$. Acute effects of cPFe on acetyl and butyrylcholinesterases have been reported in digestive gland and gills (Ghedira et al. 2009).

Biomarker responses from crabs subject to chronic exposure (in-field) (Fig. 2) are similar to those obtained after $2 \mathrm{~d}$ of acute exposure (Fig. 4), since decreased CAT and higher GR and 6PGDH activities and MDA levels are found in both cases, while no important change is found in GPX or GST activities. The highly significant decrease in CAT could be due to heme oxygenase, a metal-inducible enzyme that would destroy free heme groups, thus lowering the activity of heme-containing enzymes such as CAT (Montes Nieto et al. 2010). The increased proteolytic susceptibility of this enzyme following exposure to various oxidants has also been offered as a plausible explanation (Grune et al. 2003, Montes-Nieto et al. 2007). We also observed a significant CAT decrease after $\mathrm{CPFe}$ exposure, both in digestive gland and gills (Fig. 4). GR showed an increase (both organs) after exposure to $\mathrm{Cd}$ and to the mixture (gills), but not after OP exposure alone (Fig. 4). However, a significantly higher GR was observed at GAR than at BIZ (Fig. 2), even though higher Cd levels were measured at the last sampling site, both in sediments and organs (Table 1). 6PGDH was also found to be significantly higher only at GAR (Fig. 2), coinciding with the $\mathrm{CPFe}$ and $\mathrm{Cd}-\mathrm{cPFe}$ acute-exposure (Fig. 4).

We wish to highlight the much higher lipid oxidative damage in gills than in the digestive gland, although both organs accumulated metals to a similar extent, $\mathrm{Cd}$ levels being even higher in the digestive gland. MDA in GAR crab gills was $1.37 \pm$ $0.24 \mathrm{nmol} \mathrm{mg}^{-1}$ of protein (Fig. 2), rising to $1.64 \pm$

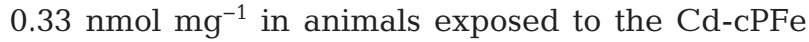

mixture (Fig. 4). This is 2 orders of magnitude higher than in the digestive gland, where MDA ranged from 0.012 to $0.036 \mathrm{nmol} \mathrm{mg}^{-1}$. Gills are much more sensitive than the digestive gland to pollutant exposure, and a high proportion of DNA strand breaks and a positive dose-response relationship between DNA damage and $\mathrm{Cd}$ levels has been shown in gills, but not in the digestive gland (Pan \& Zhang 2006). Oxidative damage and mitochondrial alterations have also been reported in gills, but not in the digestive gland, of the crab Potamonautes warreni exposed to $0.2 \mathrm{mg}$ $\mathrm{Cd}^{2+} \mathrm{l}^{-1}$ (Schuwerack \& Lewis 2003). Digestive glands have accumulative defence and detoxification mechanisms, not sufficiently developed in gills, to better protect from oxidative stress. Further, higher $\mathrm{O}_{2}$ levels are found in gills than in the digestive gland, also explaining the more intense lipid oxidative damage of gills, a key organ in gas exchange. Since the similar activities of the antioxidant enzymes measured here cannot explain lipid peroxidation differences between these two organs, other mechanisms must be involved.

Although metals such as $\mathrm{Cd}$ induce oxidative stress, especially in gills, thus increasing lipid peroxidation (Fig. 4), the metal content we measured in sediments and crab organs from the Tunisian littoral area (Table 1) does not correlate clearly with oxidative biomarker responses (Fig. 2), as shown by PCA analysis (Fig. 3). Metal levels were much higher at BIZ, both in sediments and in Carcinus maenas organs, than at the other 2 sites, following the order BIZ $\gg$ GAR $\geq T E B$. In contrast, GAR crabs showed higher oxidative stress responses, the order being GAR $\gg$ BIZ $\geq$ TEB. In C. maenas from another metalpolluted coastal system (Óbidos Lagoon, Portugal), oxidative stress and biotransformation responses were not directly attributable to metal concentrations in the digestive gland; additive effects of metals, nutrients, alterations in dissolved oxygen and other abiotic variables, and their interactions (synergism, potentiation) could be crucial in inducing biochemical responses (Pereira et al. 2009). How the variability in physico-chemical parameters in estuarine regions can affect biochemical and physiological responses, by altering the bioavailability and the toxicity of pollutants, has been reviewed by Monserrat et al. (2007). The use of more holistic and unbiased proteomic approaches could help to clarify the complexity of responses and interactions (LópezBarea \& Gómez-Ariza 2006, Monserrat et al. 2007). Recent monitoring studies of Tunisian coasts, using nereid worms have shown similar contamination values, corresponding to a 'critically contaminated envi- 
ronment' in BIZ and GAR (Bouraoui et al. 2010). However, in the clam Ruditapes decussatus, greater contamination has been found at GAR than at BIZ (Banni et al. 2005). High levels of organic contaminants from agricultural, industrial and domesticurban sources, capable of inducing ROS production, may be present at GAR, thus contributing to its higher pollution level and elevated oxidative stress condition. High levels of petroleum hydrocarbons (from oil transportation, shipping and industrial activities, urban runoff and waste discharge) have been found along the coasts of Sfax and Gabès Gulf (Louati et al. 2001, Zaghden et al. 2005). It should be noted that pesticides (cPFe), alone or in company with metals, increase lipid peroxidation well above levels induced by Cd exposure (Fig. 4).

\section{CONCLUSIONS}

The present study shows that, given the increasing number and diversity of pollutants dumped into the marine environment and the high cost of chemical measurements of water and sediment quality, biomarker assessment in sentinel organisms is an effective method for predicting detrimental effects and evaluating toxicity of pollutant mixtures. In our study, a set of early-warning exposure biomarkers (several antioxidant enzymes) and an effect biomarker (MDA) were analyzed in crab tissues (liver and gills). CAT and MDA were the most sensitive biomarkers and gills the most responsive organ. A lower CAT activity in gills is associated with higher MDA levels. Nevertheless, although the response of conventional biomarkers has been well established, they can be biased and may give only partial information (Vioque-Fernández et al. 2009, Montes Nieto et al. 2010). For this reason, we are presently carrying out a more general and comprehensive proteomic study using 2-dimensional electrophoresis and mass spectrometry analysis in the same areas along the Tunisian littoral zone, to elucidate new and unbiased pollution biomarkers.

Acknowledgements. This work was funded by a mobility grant (A/016113/08) from the Spanish Ministry of Foreign Affairs, Spanish Agency of International Cooperation, within the Spain-Tunisia program, and a grant (CTM200912858-C02) from the Spanish Ministry of Science and Education. The authors also thank the Ministry of Higher Education, Scientific Research and Technology, Tunisia (Unité de Recherche en Biochimie et Toxicologie Environnementale grant no. UR 04AGR05), and the Institution de la Recherche et de l'Enseignement Supérieur Agricole, Tunisia.

\section{LITERATURE CITED}

Allan IJ, Vrana B, Greenwood R, Mills GA, Roig B, Gonzalez C (2006) A 'toolbox' for biological and chemical monitoring requirements for the European Union's Water Framework Directive. Talanta 69:302-322

ANPE (Agence Nationale de la Protection de l'Environnement) (1989) Diagnostic préliminaire pour l'étude de l'équilibre écologique du lac de Bizerte. Agence Nationale de la Protection de l'Environnement, Aryanah

Banni M, Jebali J, Daubeze M, Clerandau C, Guerbej H, Narbonne JF, Boussetta H (2005) Monitoring pollution in Tunisian coasts: application of a classification scale based on biochemical markers. Biomarkers 10:105-116

> Banni M, Dondero F, Jebali J, Guerbej H, Boussetta H, Viarengo A (2007) Assessment of heavy metal contamination using real-time PCR analysis of mussel metallothionein $m t 10$ and $m t 20$ expression: a validation along the Tunisian coast. Biomarkers 12:369-383

> Banni M, Bouraoui Z, Clerandeau C, Narbonne JF, Boussetta $H$ (2009a) Mixture toxicity assessment of cadmium and benzo[a]pyrene in the sea worm Hediste diversicolor. Chemosphere 77:902-906

Banni M, Bouraoui Z, Ghedira J, Clearandeau C, Jebali J, Boussetta H (2009b) Seasonal variation of oxidative stress biomarkers in clams Ruditapes decussatus sampled from Tunisian coastal areas. Environ Monit Assess 155:119-128

Bouraoui Z, Banni M, Chouba L, Ghedira J and others (2010) Monitoring pollution in Tunisian coasts using a scale of classification based on biochemical markers in worms Nereis (Hediste) diversicolor. Environ Monit Assess 164: 691-700

Bradford MM (1976) A rapid and sensitive method for the quantitation of microgram quantities of protein utilizing the principle of protein-dye binding. Anal Biochem 72: 248-254

Brown RK, Kelly FJ (1996) Peroxides and other products. In: Punchard NA, Kelly FJ (eds) Free radicals: a practical approach. IRL Press at Oxford University Press, Oxford, p 119-131

Brown RJ, Galloway TS, Lowe D, Browne MA, Dissanayake A, Jones MB, Depledge MH (2004) Differential sensitivity of three marine invertebrates to copper assessed using multiple biomarkers. Aquat Toxicol 66:267-278

Carlton JT, Cohen AN (2003) Episodic global dispersal in shallow water marine organisms: the case history of the European shore crabs Carcinus maenas and C. aestuarii. J Biogeogr 30:1809-1820

> Casalino E, Sblano C, Landriscina C (1997) Enzyme activity alteration by cadmium administration to rats: the possibility of iron involvement in lipid peroxidation. Arch Biochem Biophys 346:171-179

Casalino E, Calzaretti G, Sblano C, Landriscina C (2002) Molecular inhibitory mechanisms of antioxidant enzymes in rat liver and kidney by cadmium. Toxicology 179:37-50

CGP (Commiseriat Générale de Pêche) (1996) Annuaire des statistiques des pêches en Tunisie. Ministère de l'agriculture, Tunis

> Dellali M, Gnassia Barelli M, Romeo M, Aissa P (2001) The use of acetylcholinesterase activity in Ruditapes decussatus and Mytilus galloprovincialis in the biomonitoring of Bizerta lagoon. Comp Biochem Physiol C Toxicol Pharmacol 130:227-235 
Domingues I, Guilhermino L, Soares AMVM, Nogueira AJA, Monaghan KA (2009) Influence of exposure scenario on pesticide toxicity in the midge Kiefferulus calligaster (Kieffer). Ecotoxicol Environ Saf 72:450-457

Flohé L (1989) Structure and catalytic mechanism of glutathione peroxidase. In: Taniguchi N, Higashi T, Sakamoto Y, Meister A (eds) Glutathione centennial: molecular perspectives and clinical implications. Academic Press, London, p 103-114

> Ghedira J, Jebali J, Bouraoui Z, Banni M, Chouba L, Boussetta H (2009) Acute effects of chlorpyryphos-ethyl and secondary treated effluents on acetylcholinesterase and butyrylcholinesterase activities in Carcinus maenas. J Environ Sci (China) 21:1467-1472

> Grune T, Merker K, Sandig G, Davies KJ (2003) Selective degradation of oxidatively modified protein substrates by the proteasome. Biochem Biophys Res Commun 305: 709-718

Gutteridge JM (1984) Ferrous ion-EDTA-stimulated phospholipid peroxidation: a reaction changing from alkoxylradical- to hydroxyl-radical-dependent initiation. Biochem J 224:697-701

> Hamza-Chaffai A, Pellerin J, Amiard JC (2003) Health assessment of a marine bivalve Ruditapes decussatus from the Gulf of Gabès (Tunisia). Environ Int 28:609-617

> Hebel DK, Jones MB, Depledge MH (1997) Responses of crustaceans to contaminant exposure: a holistic approach. Estuar Coast Shelf Sci 44:177-184

Hyne RV, Maher WA (2003) Invertebrate biomarkers: links to toxicosis that predict population decline. Ecotoxicol Environ Saf 54:366-374

> Jebali J, Banni M, de Almeida E, Boussetta H (2007) Oxidative DNA damage levels and catalase activity in the clam Ruditapes decussatus as pollution biomarkers of Tunisian marine environment. Environ Monit Assess 124: 195-200

Khessiba A, Hoarau P, Gnassia-Barelli M, Aissa P, Romeo M (2001) Biochemical response of the mussel Mytilus galloprovincialis from Bizerta (Tunisia) to chemical pollutant exposure. Arch Environ Contam Toxicol 40:222-229

> Li K, Chen LQ, Li EC, Zhou ZK (2006) Acute toxicity of the pesticides chlorpyrifos and atrazine to the Chinese mittenhanded crab, Eriocheir sinensis. Bull Environ Contam Toxicol 77:918-924

> Long ER, MacDonald DD, Smith SL, Calder FD (1995) Incidence of adverse biological effects within ranges of chemical concentrations in marine and estuarine sediments. Environ Manage 19:81-97

López-Barea J (1995) Biomarkers in ecotoxicology: an overview. Arch Toxicol Suppl 17:57-79

> López-Barea J, Gómez-Ariza JL (2006) Environmental proteomics and metallomics. Proteomics 6:S51-S62

> Louati A, Elleuch B, Kallel M, Saliot A, Dagaut J, Oudot J (2001) Hydrocarbon contamination of coastal sediments from the Sfax area (Tunisia), Mediterranean Sea. Mar Pollut Bull 42:445-452

> Louiz I, Ben-Attia M, Ben-Hassine OK (2009) Gonadosomatic index and gonad histopathology of Gobius niger (Gobiidea, Teleost) from Bizerta lagoon (Tunisia): evidence of reproduction disturbance. Fish Res 100:266-273

> Machreki-Ajmi M, Ketata I, Ladhar-Chaabouni R, HamzaChaffai A (2008) The effect of in situ cadmium contamination on some biomarkers in Cerastoderma glaucum. Ecotoxicology 17:1-11

Martín-Díaz ML, Blasco J, Sales D, DelValls TA (2004) Bio- markers as tools to assess sediment quality: laboratory and field surveys. Trends Analyt Chem 23:807-818

Martín-Díaz ML, Villena-Lincoln A, Bamber S, Blasco J, DelValls TA (2005) An integrated approach using bioaccumulation and biomarker measurements in female shore crab, Carcinus maenas. Chemosphere 58:615-626

> Martín-Díaz ML, Blasco J, Sales D, DelValls TA (2007) Biomarkers study for sediment quality assessment in Spanish ports using the crab Carcinus maenas and the clam Ruditapes philippinarum. Arch Environ Contam Toxicol 53:66-76

> Martín-Díaz ML, Blasco J, Sales D, DelValls TA (2008) Field validation of a battery of biomarkers to assess sediment quality in Spanish ports. Environ Pollut 151:631-640

Martín-Díaz ML, Blasco J, Sales D, DelValls TA (2009) The use of a kinetic biomarker approach for in situ monitoring of littoral sediments using the crab Carcinus maenas. Mar Environ Res 68:82-88

Monserrat JM, Geracitano LA, Bianchini A (2003) Current and future perspectives using biomarkers to assess pollution in aquatic ecosystems. Comments Toxicol 9:225-269

> Monserrat JM, Martínez PE, Geracitano LA, Amado LL and others (2007) Pollution biomarkers in estuarine animals: critical review and new perspectives. Comp Biochem Physiol C Toxicol Pharmacol 146:221-234

Montes-Nieto R, Fuentes-Almagro CA, Bonilla-Valverde D, Prieto-Álamo MJ and others (2007) Proteomics in free-living Mus spretus to monitor terrestrial ecosystems. Proteomics 7:4376-4387

Montes-Nieto R, García-Barrera T, Gómez-Ariza JL, LópezBarea J (2010) Environmental monitoring of Domingo Rubio stream (Huelva Estuary, SW Spain) by combining conventional biomarkers and proteomic analysis in Carcinus maenas. Environ Pollut 158:401-408

> Pan L, Zhang H (2006) Metallothionein, antioxidant enzymes and DNA strand breaks as biomarkers of Cd exposure in a marine crab, Charybdis japonica. Comp Biochem Physiol C Toxicol Pharmacol 144:67-75

Patrick L (2003) Toxic metals and antioxidants: Part II. The role of antioxidants in arsenic and cadmium toxicity. Altern Med Rev 8:106-128

Pedersen SN, Pedersen KL, Hojrup P, Knudsen J, Depledge $\mathrm{MH}$ (1998) Induction and identification of cadmium-, zinc- and copper-metallothioneins in the shore crab Carcinus maenas (L.). Comp Biochem Physiol C Pharmacol Toxicol Endocrinol 120:251-259

Pereira P, de Pablo H, Dulce Subida M, Vale C, Pacheco M (2009) Biochemical responses of the shore crab (Carcinus maenas) in a eutrophic and metal-contaminated coastal system (Óbidos lagoon, Portugal). Ecotoxicol Environ Saf 72:1471-1480

Pickett C (1989) Regulation of glutathione-S-transferase gene expression. In: Taniguchi N, Higashi T, Sakamoto Y, Meister A (eds) Glutathione centennial: molecular perspectives and clinical implications. Academic Press, London, p 129-136

PNUE/COI/AIEA/FAO (Programme des Nations Unies pour l'Environnement/Commission Océanographique Intergouvernementale/l'Agence Internationale de l'Energie Atomique/Food and Agriculture Organization) (1994) Programme de surveillance continue des contaminants utilisant des organismes marins: assurance de la qualité et bonnes pratiques de laboratoire. Méthodes de référence pour les études de la pollution marine, no. 57. Programme des Nations Unies pour l'Environnement, Geneva 
Rainbow PS (1998) Phylogeny of trace metal accumulation in crustaceans. In: Angston WJ, Bebianno MJ (eds) Metal metabolism in aquatic environments. Chapman \& Hall, London, p 285-319

Ray S (1986) Bioaccumulation of cadmium in marine organisms. Experientia Suppl 50:65-75

Rodríguez-Ariza A, Abril N, Navas JI, Dorado G, LópezBarea J, Pueyo C (1992) Metal, mutagenicity, and biochemical studies on bivalve molluscs from Spanish coasts. Environ Mol Mutagen 19:112-124

Schuwerack PM, Lewis JW (2003) The mode of action of acute and chronic concentrations of waterborne $\mathrm{Cd}$ in the digestive gland of the acclimated infested freshwater crab (Potamonautes warreni). Cell Tissue Res 312:249-263

Schuwerack PM, Lewis JW, Jones P (2001) The potential use of the South African river crab, Potamonautes warreni, as a bioindicator species for heavy metal contamination. Ecotoxicology 10:159-166

Sies H (1986) Biochemistry of oxidative stress. Angew Chem Int Ed Engl 25:1058-1071

Silvestre F, Dierick JF, Dumont V, Dieu M, Raes M, Devos P (2006) Differential protein expression profiles in anterior gills of Eriocheir sinensis during acclimation to cadmium. Aquat Toxicol 76:46-58

Simpson WR (1981) A critical review of cadmium in the marine environment. Prog Oceanogr 10:1-70

Smaoui-Damak W, Hamza-Chaffai A, Berthet B, Amiard JC

Editorial responsibility: Matthias Seaman,

Oldendorf/Luhe, Germany
(2003) Preliminary study of the clam Ruditapes decussatus exposed in situ to metal contamination and originating from the Gulf of Gabès, Tunisia. Bull Environ Contam Toxicol 71:961-970

Smaoui-Damak W, Berthet B, Hamza-Chaffai A (2009) In situ potential use of metallothionein as a biomarker of cadmium contamination in Ruditapes decussatus. Ecotoxicol Environ Saf 72:1489-1498

Valko M, Morris H, Cronin MT (2005) Metals, toxicity and oxidative stress. Curr Med Chem 12:1161-1208

Vioque-Fernández A, de Almeida EA, Ballesteros J, GarcíaBarrera T, Gómez-Ariza JL, López-Barea J (2007) Doñana National Park survey using crayfish (Procambarus clarkii) as bioindicator: esterase inhibition and pollutant levels. Toxicol Lett 168:260-268

Vioque-Fernández A, Alves de Almeida E, López-Barea J (2009) Assessment of Doñana National Park contamination in Procambarus clarkii: integration of conventional biomarkers and proteomic approaches. Sci Total Environ 407:1784-1797

Winston GW, Di Giulio RT (1991) Prooxidant and antioxidant mechanisms in aquatic organisms. Aquat Toxicol 19:137-161

Zaghden H, Kallel M, Louati A, Elleuch B, Oudot J, Saliot A (2005) Hydrocarbons in surface sediments from the Sfax coastal zone, (Tunisia) Mediterranean Sea. Mar Pollut Bull 50:1287-1294

Submitted: May 13, 2011; Accepted: September 8, 2011 Proofs received from author(s): November 8, 2011 